Intersections

Canadian Journal of Music

Revue canadienne de musique
Intersections

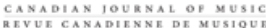

\title{
Report from Ottawa: the Canadian Bureau of International Education
}

\section{Murray Dineen}

Volume 27, numéro 2, 2007

URI : https://id.erudit.org/iderudit/1013114ar

DOI : https://doi.org/10.7202/1013114ar

Aller au sommaire du numéro

Éditeur(s)

Canadian University Music Society / Société de musique des universités

canadiennes

ISSN

1911-0146 (imprimé)

1918-512X (numérique)

Découvrir la revue

Citer ce compte rendu

Dineen, M. (2007). Compte rendu de [Report from Ottawa: the Canadian Bureau

of International Education]. Intersections, 27(2), 81-83.

https://doi.org/10.7202/1013114ar

Copyright @ Canadian University Music Society / Société de musique des universités canadiennes, 2008
Ce document est protégé par la loi sur le droit d'auteur. L'utilisation des services d'Érudit (y compris la reproduction) est assujettie à sa politique d'utilisation que vous pouvez consulter en ligne.

https://apropos.erudit.org/fr/usagers/politique-dutilisation/ 


\title{
Report From OtTaWa: the Canadian Bureau of INTERNATIONAL EDUCATION
}

\author{
Murray Dineen
}

In this brief report, I shall describe a programme of international scholarships that may be of interest to Canadian scholars and their students.

Second only to Toronto in the esteem of ordinary Canadians, Ottawa does of course spend your taxes, for better or for worse. As a member of the loosely divided Ottawa government and academic community, I have observed closely some of the lesser known federal institutions that often exert a direct influence upon our lives as academics. I have observed that if some of these institutions were better known, it might make the annual April excise a less burdensome chore. In this brief report, I draw one such institution to your attention, the Canadian Bureau of International Education (CBIE). The CBIE is particularly worthy of notice because of the opportunities it affords for study and exchange between countries. Readers who wish to learn more about the CBIE beyond the contents of this report can consult the websites listed below.

The grand rubric under which the CBIE operates is "the promotion of Canada's international relations through international education: the free movement of ideas and learners across national boundaries." But you will know their work primarily through the Commonwealth Scholarship. CBIE manages a number of excellent programmes on behalf of the Department of Foreign Affairs and International Trade (DFAIT), of which the Commonwealth Scholarship is but one. It is largely to these student scholarship programmes that I draw your attention.

\section{Scholarships Primarily for Canadian Students and RESEARCHERS}

The Commonwealth Scholarship, the best known of the CBIE scholarships, is also the most competitive, certainly for study in the United Kingdom, and the success rate is prejudiced by the sheer number of applicants. This is not the case, however, for many of the other scholarships administered by CBIE (including the DAAD scholarship with Germany, and a Master's degree scholarship for study in France), some for Canadians to study abroad and others to bring foreign students and scholars to Canadian universities. These awards are administered by the CBIE on behalf of DFAIT, and they include the following awards: the Canada-China Scholars' Exchange Program (available to Canadians for study in China), the familiar Commonwealth Scholarship Plan for study in Commonwealth countries; the Foreign Government Awards Program available 
to Canadians for study in other foreign countries, the Organization of American States (OAS) Fellowships Programs for studies and research in an OAS member state, and the Organization of American States (OAS) Professional Development Scholarships Program for Canadian institutions to offer courses or other "training activities" by which citizens of participating foreign countries might benefit. Not all scholarships are intended to support the study of the arts or culture, but some do. As both the nature and number of scholarships fluctuates from year to year, a regular perusal of the (often complex) CBIE website is recommend.

Perhaps the least known of these scholarship programmes and yet the one that offers the greatest promise for our graduate students (and undergraduates in two instances, Japan and Russia) is the Foreign Government Awards Program. Since it depends upon the implementation of cultural agreements that foreign governments strike with the Government of Canada, the governments involved will vary from year to year. The governments of Chile, Colombia, France, Germany, Korea, Mexico, the Philippines, and Russia are offering awards to Canadian graduate students, awards tenable in 2008-2009. (You should note that the governments of Italy, Japan, the Netherlands and Spain also offer awards to Canadian students, but the embassies of these countries in Canada [not the CBIE] are responsible for the administration of their scholarships.) The aim of these awards is to assist Canadian students in furthering their studies or conducting research abroad at the master's, doctoral or post-doctoral level. Normally they cover a period of at least six months, some more, some less. (The Government of Italy offers short-term scholarships of less than two months for Italian language and culture courses.) Most countries offer a wide selection of disciplines to which awards may be applied, but not all countries offer awards for all disciplines.

By way of examples, as part of the Foreign Government Awards Program, the CBIE administers the competition for the German Academic Exchange Service (DAAD, mentioned above), which offers Graduate Scholarships to highly qualified graduate students, $\mathrm{Ph}$.D. candidates, and postdoctoral researchers for study or research at universities or institutes in the Federal Republic of Germany. It administers as well a Master's level scholarship to enable Canadians studying in Canada (excluding Québec, which has other agreements with France) to study at a French university. Scholarships are for a period of four months.

The CBIE makes an initial selection of candidates for the student awards by means of a screening conducted here in Ottawa by the Canadian Scholarship Selection Committee, but the final selection is made by the host country. Having served for two years as a member of the Selection Committee, I have observed that few students of music apply for these awards, and in some competitions there are no applications from the arts and the artistic humanities at all. The quality of the application must be high (usually supported by evidence of strong academic achievement and community involvement), but I believe more of our students would take an interest in a study or research sabbatical in Germany or France, or in the participant Third World countries (in particular students involved in ethnomusicology or cultural studies), if these programmes were better known. 


\section{SCHOLARSHIPS PRIMARILY FOR FOREIGN STUDENTS AND}

\section{RESEARCHERS}

The Government of Canada offers scholarships for foreign students as part of the Canadian Commonwealth Scholarship Program (for students of other Commonwealth countries to pursue research and studies in Canada) and the Government of Canada Awards (to provide opportunities for students of certain non-Commonwealth foreign countries to pursue research and studies in Canada). These scholarships are tenable at recognized Canadian publicly funded universities and colleges.

One particularly noteworthy endeavour is the Graduate Students' Exchange Program, the goal of which is to encourage Canadian universities and colleges to develop or expand their exchange programs. The objective is to provide opportunities for students from a number of eligible countries to participate in existing exchange programs. The onus falls upon the Canadian institution to make the application on behalf of the student. The list of eligible countries includes those from Sub-Saharan Africa, Latin America and the Carribean, and the Asia-Pacific region. While the programme is intended to develop existing exchange programmes, the CBIE welcomes expressions of interest in developing new exchange agreements with institutions abroad.

Another programme of potential benefit to Canadian scholars and their institutions is the Canadian Post-Doctoral Research Fellowships Competition, designed to provide research opportunities to promising recent doctoral graduates in the humanities, social sciences, natural sciences, and engineering (but not professional artists). The value of the fellowship is $\$ 32,000$ (Canadian) for 12 months non renewable (the CBIE being more than concerned about draining expert resources from other countries). The host university must demonstrate how the researcher will be incorporated full-time into research activities here in Canada.

The home page of the CBIE is <http://www.cbie.ca/>. An overview of the scholarship programmes is at $<$ http://www.cbie.ca/english/scholarship/default. htm>. The DFAIT scholarship website is <http://www.scholarships.gc.ca/ canadians-en.html >. I encourage you to draw these to the attention of your students in particular. 